ISSN 1392-3196 / e-ISSN 2335-8947

Zemdirbyste-Agriculture, vol. 102, No. 1 (2015), p. 41-50

DOI 10.13080/z-a.2015.102.005

\title{
The relationship of potato tubers chemical composition with selected physiological indicators
}

\author{
Barbara SAWICKA ${ }^{1}$, Władysław MICHAŁEK ${ }^{1}$, Piotr PSZCZÓŁKOWSKI \\ ${ }^{1}$ University of Life Sciences in Lublin \\ Akademicka 15, 20-950 Lublin, Poland \\ E-mail: barbara.sawicka@up.lublin.pl \\ ${ }^{2}$ Variety Assessment Experimental Station of Research Centre For Cultivar Testing \\ Uhnin, 21-211 Dębowa Kłoda, Poland
}

\begin{abstract}
The paper deals with the analysis of a ten-year study on the chemical composition of tubers of forty potato cultivars and their physiological indicators. The research was carried out at the experimental station in Parczew, Poland on a podzolic soil with typical granulometric composition of sandy silty clay, using a randomized block design in four replicates. Forty potato cultivars were the subject of this study, including eight very early, seven early, nine medium early, nine medium late and seven late cultivars. The photosynthetic activity of plants was evaluated by measuring chlorophyll $a$ and $b$ determined in raw leaf matter by the spectrophotometric method as well as by measurements of chlorophyll fluorescence induction of potato leaves using a fluorimeter PAM-2000. Measurements of photosynthetic indicators at various stages of potato development revealed that their increase indirectly reflected the prolongation of plant growing period, which might have a direct impact on yield quality. The chemical composition was determined by standard methods used for tubers. The main objective of the study was to determine the chemical composition of potato depending on the values of chlorophyll fluorescence indicators, which will allow prediction of the chemical composition of tubers during the growing season. The obtained results allow us to predict changes in nutrient content in potato tubers based on the indicators such as: chlorophyll $a$ and $b$ content, minimum and maximum fluorescence yield, maximum efficiency of photosystem in dark and mean plant growth rate.
\end{abstract}

Key words: chemical composition, chlorophyll, cultivar, maximum efficiency of photosystem, Solanum tuberosum.

\section{Introduction}

Potato is one of the plant species that are the most effective in transforming the solar energy into human food, both quantitatively and qualitatively (Caldiz et al., 2001; Michałek, Sawicka, 2005; Lamperski, 2007; Struik, 2007; Caldiz, 2009; Loboda, 2010; Kalaji et al., 2011; Brestic et al., 2012; Bahari et al., 2013). High maximum efficiency of photosystem (PS) II $\left(\mathrm{F}_{\mathrm{F}} / \mathrm{F}_{\mathrm{m}}\right)$ indicates relatively high potential efficiency of PSII. According to Sadras et al. (2009), it is a quite good physiological indicator for evaluating the interactions of abiotic and biotic factors affecting plants. Starck (2014) indicated that the chlorophyll fluorescence induction parameters allow estimating the course and efficiency of photochemical reactions during the light phase, leading to produce the so-called "assimilation force", and their relationships with enzymatic reactions during the dark phase of photosynthesis. Michałek and Sawicka (2005) as well as Loboda (2010) agree that the values of particular chlorophyll fluorescence indicators mainly depend on the genetic properties of cultivars which produce their own assimilates in an individual and specific manner. Starck (2010) suggested that stress conditions may invoke disorganization in the chloroplast membranes, which directly affects the lower efficiency of PSII. Field-cultivated plants are influenced by a wide spectrum of stress factors, such as low or high temperatures, water deficit, excessive radiation within the photosynthetically active range, mechanical injuries, gaseous contamination, phytotoxins, herbicides applied, or intensive fertilization, mainly with nitrogen. These factors disturb the growth and development of plants and consequently affect yields. Photosynthesis is a metabolic process that is very sensitive to stress factors. Paul and Foyer (2001) assume that usually not only a single factor but several stress factors have simultaneous effects on a plant and thus the so-called multi-stress occurs. According to Kalaji et al. (2012) and Starck (2014), such stress results in photoinhibition of photosynthetic reactions, which manifests mainly as the destruction of PSII as well as the slowing down of the electron transport in both photosystems (Czyczylo-Mysza et al., 2013). In the case of prolonged photoinhibition, oxidation stress may be invoked in plant tissues, which leads to freeradical lipid oxidation within chloroplast membranes as well as to oxidation of photosynthetic pigments. Both the photoinhibition effects and disintegration of the photosynthetic apparatus make the values of the chlorophyll fluorescence parameters change. The phloem plasmodesmata take part in the regulation of loading and unloading processes, perhaps by sorting 
macromolecules during their passing through them. In the companion cells the expression of many genes takes place and their products are loaded into sieve tubes; therefore they are indirectly involved in the mechanism of phloem transport. The presented data, concerning regulation of plant processes indicate that they developed a very robust, signalling and information-processing apparatus of chemical and physical pathways (Starck, 2011). Due to the fact that a quite a broad spectrum of potato cultivars with a diverse chemical composition of tubers and various physiological properties are cultivated in Poland, there is a need to evaluate the relationship between these traits, which could make it possible to select cultivars characterized by physiological features that would allow a beneficial chemical composition of tubers to be achieved.

\section{Material and methods}

The results were obtained from a strictly controlled 10-year (2001-2010) field experiment carried out at the experimental station in Parczew, Lubelskie Voivodeship, Poland on a light soil of the rye complex using a randomized block design in four replicates. Forty potato (Solanum tuberosum L.) cultivars were the subject of this study, including eight very early ('Accent', 'Aster', 'Bard', 'Drop', 'Denar', 'Irys', 'Lord', 'Orlik'), seven early ('Aksamitka', 'Albina', 'Bila', 'Karlena', 'Latona', 'Sumak', 'Vineta'), nine medium early ('Barycz', 'Baszta', 'Glada', 'Harpun', 'Ibis', 'Ikar', 'Irga', 'Klepa', 'Mila'), nine medium late ('Ania', 'Anielka', 'Arkadia', 'Bryza', 'Danusia', 'Fregata', 'Panda', 'Salto', 'Wolfram') and seven late ('Bzura', 'Dunajec', 'Hinga', 'Jantar', 'Jasia', 'Meduza', 'Wawrzyn'). Mineral nutrition at a constant level $\left(\mathrm{N}-90, \mathrm{P}_{2} \mathrm{O}_{5}-90, \mathrm{~K}_{2} \mathrm{O}-\right.$ $135 \mathrm{~kg} \mathrm{ha}^{-1}$ ) was applied in summer before planting, while organic fertilization in the form of cattle manure composed of: dry matter $-24 \%, \mathrm{~N}-21.5 \mathrm{~g} \mathrm{~kg}^{-1} \mathrm{dm}^{-3}, \mathrm{P}-$ $6.1 \mathrm{~g} \mathrm{~kg}^{-1} \mathrm{dm}^{-3}, \mathrm{~K}-15.7 \mathrm{~g} \mathrm{~kg}^{-1} \mathrm{dm}^{-3}, \mathrm{Ca}-7.8 \mathrm{~g} \mathrm{~kg}^{-1} \mathrm{dm}^{-3}$ at a rate of $25 \mathrm{t} \mathrm{ha}^{-1}$ was used in autumn. The health of seed tubers was comparable (health class C/A). Planting and all other agronomic operations were carried out in accordance with good agricultural practices. During the harvest, tuber samples were collected for chemical determinations. Chemical analyses of raw material were performed just after the harvest in three replicates. Dry matter in tubers was determined by drying at $105^{\circ} \mathrm{C}$, according to the standard method; starch content was evaluated using Evans polarimetric method; total sugars and reducing sugars content - according to HagedornJensen with Brzeski and Kaniuga modifications; total protein - by Kjeldahl method using an automated system Kjeltec $^{\mathrm{TM}} 2100$ (FOSS Inc., Denmark); specific protein as protein insoluble in $10 \%$ trichloroacetic acid (AOAC, 2012); crude fibre - according to Scharrer and Kürschner (Baryłko-Pikielna, Matuszewska, 2014); vitamin C spectrophotometrically by the xylene method; nitrates following the standard PN-EN 12014-7 (2001).

The following physiological traits were determined: chlorophyll $a$ and $b$ content in raw leaf matter; mean leaf assimilation surface area; mean growth rate according to Starck (2010), as well as the following chlorophyllfluorescence parameters: maximum efficiency of photosystem (PS) II in the dark $\left(\mathrm{F}_{\mathrm{v}} / \mathrm{F}_{\mathrm{m}}\right)$, efficiency of PSII in the light $\left(\mathrm{F}_{\mathrm{v}} / \mathrm{F}_{\mathrm{m}}\right)$, maximum fluorescence efficiency $(\mathrm{Y})$, quantum yield of chlorophyll $\left(\Phi_{\mathrm{PSII}}\right)$, coefficient of photochemical fluorescence quenching $\left(q_{p}\right)$ and coefficient of non-photochemical fluorescence quenching $\left(q_{n}\right)$.

The photosynthetic activity of plants was evaluated by measuring chlorophyll $a$ and $b$ determined in raw leaf matter by the spectrophotometric method as well as by measurements of chlorophyll fluorescence induction of potato leaves using a fluorimeter PAM-2000 (Walz GmbH, Germany) at three growth stages: full emergence, full bloom and beginning of leaf senescence according to Schreiber et al. (1997). The chlorophyll fluorescence was measured at the third true leaf according to the standard method. All measurements were made in four replicates.

The study results were statistically processed applying variance, correlation, and polynomial regression analyses. Significance of sources of variation was verified using the Fisher-Snedecor test. The functional parameters were evaluated by means of the least squares method, while significance was verified using the Student's $t$-test. During all calculations, the dependent variables (y) were the content of: $y_{1}-$ dry matter, $y_{2}-$ starch, $y_{3}$ - total sugars, $y_{4}$ - reducing sugars, $y_{5}-$ total protein, $y_{6}$ - specific protein, $y_{7}-$ crude fibre, $y_{8}-$ ash, $y_{9}-$ vitamin $\mathrm{C}, y_{10}$ - nitrates; whereas the independent variables $(x)$ were the following: $x_{1}-$ mean leaf assimilation surface area, $x_{2}$ - chlorophyll $a, x_{3}$ - chlorophyll $b, x_{4}$ - minimum fluorescence yield $\left(\mathrm{F}_{0}\right), x_{5}-$ maximum fluorescence yield $\left(\mathrm{F}_{\mathrm{m}}\right), x_{6}$ - maximum efficiency of PSII in the dark $\left(\mathrm{F}_{\mathrm{v}} / \mathrm{F}_{\mathrm{m}}\right), x_{7}$ - efficiency of PSII in the light $\left(\mathrm{F}_{\mathrm{v}} / \mathrm{F}_{\mathrm{m}}\right), x_{8}-$ maximum fluorescence efficiency $(\mathrm{Y}), x_{9}$ - quantum yield of chlorophyll $\left(\Phi_{\mathrm{PSII}}\right), x_{10}-$ coefficient of photochemical fluorescence quenching $\left(\mathrm{q}_{\mathrm{p}}\right), x_{11}-$ coefficient of non-photochemical fluorescence quenching $\left(\mathrm{q}_{\mathrm{n}}\right), x_{12}-$ mean growth rate. Variables for multivariate linear regression were selected on the basis of straight correlation coefficients. Regressions presented in tables were approximated according to a general equation: $y=a+b_{j} x_{j}$, where $y$-dependent variable, $a$ - constant, $b$ - regression coefficient and $x$-independent variable. The partial regression coefficient $\left(b_{j}\right)$ indicates how the chemical composition of tubers can change if a given parameter changes by a unit. The variation of the results was characterized by the following: arithmetic mean, standard deviation and coefficient of variation (V).

Selyaninov's hydrothermal coefficient is best characterized by meteorological conditions during the growing period of potato. The most favourable conditions for the accumulation of nutrients in potato tubers were in 2003, while the least favourable were during the years 2001, 2002 and 2004. During tuberization, extreme drought occurred only in 2002; a drought in the years 2009 and 2010, while in 2002, 2003, 2007 and 2008 there was excessive humidity. During the main stage of potato growth (flowering), extreme drought occurred in 2002, 2006 and 2008, while in the years 2001, 2003, 2005, 2009 and 2010 there was excessive humidity (Table 1). 
Table 1. Selyaninov's hydrothermal coefficient during the potato growing period (2001-2010) for Parczew, Poland

\begin{tabular}{ccccccccc}
\hline \multirow{2}{*}{ Year } & \multicolumn{8}{c}{ Month } \\
\cline { 2 - 8 } & 04 & 05 & 06 & 07 & 08 & 09 & 10 & \\
\hline 2001 & 0.4 & 0.8 & 1.5 & 1.3 & 0.8 & 1.4 & 0.3 & 0.9 \\
2002 & 1.3 & 1.2 & 0.5 & 0.5 & 1.3 & 1.5 & 0.2 & 0.9 \\
2003 & 2.1 & 1.3 & 1.4 & 1.5 & 1.5 & 1.3 & 1.5 & 1.5 \\
2004 & 1.5 & 1.1 & 0.9 & 0,8 & 0.6 & 1.2 & 0.3 & 0.9 \\
2005 & 2.2 & 1.4 & 0.9 & 1.3 & 0.6 & 0.5 & 2.4 & 1.3 \\
2006 & 4.1 & 1.3 & 0.9 & 0.5 & 1.1 & 0.2 & 1.3 & 1.4 \\
2007 & 0.7 & 1.9 & 1.9 & 0.7 & 1.2 & 0.3 & 0.2 & 1.0 \\
2008 & 1.1 & 1.6 & 1.1 & 0.3 & 4.6 & 0.3 & 0.7 & 1.4 \\
2009 & 0.8 & 2.4 & 0.8 & 1.6 & 0.3 & 1.3 & 0.6 & 1.1 \\
2010 & 1.4 & 1.4 & 0.7 & 1.5 & 1.0 & 1.1 & 0.7 & 1.1 \\
\hline
\end{tabular}

$\mathrm{k} \leq 0.50$ - strong drought, $0.50 \leq \mathrm{k} \leq 0.69-$ drought, $0.70 \leq$ $\mathrm{k} \leq 0.99$ - slight drought, $\mathrm{k} \leq 1-$ no drought (according to Kożuchowski et al., 2013)

\section{Results}

The stability of the chemical composition of tubers as well as the physiological growth parameters were evaluated by means of the variation coefficient
(V) which is independent of the units and allows both trait types to be compared to one another. The values of the variation coefficient for individual tubers and of the photosynthetic efficiency indicators varied (Tables 2-3). Parameters of tuber chemical composition such as total sugars $(\mathrm{V}=4.01 \%)$, vitamin $\mathrm{C}(\mathrm{V}=5.93 \%)$, and reducing sugars $(\mathrm{V}=6.69 \%)$ were characterized by the lowest variation coefficient, which can prove quite high stability of these chemical components in tubers of very early, early, and medium early cultivars. Nitrate content $(75.77 \%)$ was reported to be the least stable feature of potato tubers (Table 2). The low value of the standard deviation, for example, for the dry matter content of tubers shows a high concentration of dry matter. Kurtosis ranged between -0.57 for crude fibre and 2.33 for total sugars (Table 2).

The skewness coefficient is set to zero for asymmetric distribution, negative values for distributions withleft-sidedasymmetry(left-handextendeddistribution) and positive values for distributions with right-sided asymmetry (right-hand extended distribution). A negative value for the left-hand asymmetric distributions (lefthand extended decomposition) was observed for total

Table 2. Statistical characteristics of dependent variables $(y)$

\begin{tabular}{|c|c|c|c|c|c|c|c|c|c|}
\hline Description & $\begin{array}{l}\text { Arithmetical } \\
\text { means }\end{array}$ & Median & $\begin{array}{l}\text { Standard } \\
\text { deviation }\end{array}$ & Kurtosis & Skewness & Range & Minimum & Maximum & $\begin{array}{c}\text { Variation } \\
\text { coefficient } \\
\%\end{array}$ \\
\hline Dry matter $\%\left(y_{1}\right)$ & 24.33 & 24.78 & 3.47 & -0.45 & 0.01 & 14.45 & 16.93 & 31.97 & 14.26 \\
\hline Starch $\%\left(y_{2}\right)$ & 16.56 & 16.80 & 2.98 & 0.35 & 0.64 & 14.30 & 11.00 & 25.30 & 18.03 \\
\hline Total sugars $\%\left(y_{3}\right)$ & 0.45 & 0.45 & 0.02 & 2.33 & -1.18 & 0.10 & 0.39 & 0.48 & 4.01 \\
\hline Reducing sugars $\%\left(y_{4}\right)$ & 0.15 & 0.15 & 0.01 & 0.21 & 0.15 & 0.05 & 0.13 & 0.18 & 6.69 \\
\hline Total protein $\%\left(y_{5}\right)$ & 1.87 & 1.92 & 0.28 & -0.44 & -0.08 & 1.31 & 1.28 & 2.57 & 15.04 \\
\hline Specific protein $\%\left(y_{6}\right)$ & 1.36 & 1.32 & 0.27 & -0.41 & 0.45 & 1.20 & 0.83 & 2.03 & 19.93 \\
\hline Crude fibre $\%\left(y_{7}\right)$ & 0.56 & 0.55 & 0.11 & 0.60 & 0.41 & 0.54 & 0.31 & 0.85 & 19.48 \\
\hline Ash \% $\left(y_{8}\right)$ & 1.32 & 1.30 & 0.17 & -0.57 & 0.37 & 0.70 & 1.02 & 1.72 & 12.82 \\
\hline Vitamin C $\mathrm{mg} \mathrm{kg}^{-1}\left(y_{9}\right)$ & 26.12 & 26.09 & 1.55 & -0.43 & -0.14 & 6.86 & 22.18 & 29.04 & 5.93 \\
\hline Nitrates mg kg-1 $\left(y_{10}\right)$ & 183.71 & 157.57 & 139.20 & 0.18 & 0.82 & 610.21 & 5.53 & 615.74 & 75.77 \\
\hline
\end{tabular}

sugars, total protein and vitamin C. Negative kurtosis for these traits indicates a flattening of their range. A positive coefficient of skewness for dry matter, starch, reducing sugars, specific protein, crude fibre, ash and nitrates is evidence of right-hand distribution of these features around the mean or right-hand asymmetry. In contrast to the standard deviation, which determines the characteristics of absolute differences, the coefficient of variation is a measure of the absolute, depending on the value of the arithmetic mean, and a measure of the spread of the results. As regards the chemical composition of tubers, vitamin $\mathrm{C}(75.77 \%)$ showed the greatest variation among the examined characters, while the lowest variation was found for total sugars $(4.01 \%)$. This means that in the conditions of south-eastern Poland, the most stable is the sum of the content of sugars, whereas the nitrate content in potato tubers is the most variable.

Among the photosynthetic efficiency indictors, photochemical fluorescence quenching coefficient $\left(q_{p}\right)$ $(\mathrm{V}=5.2 \%)$, current chlorophyll quantum efficiency $\left(\Phi_{\mathrm{PSII}}\right)(\mathrm{V}=6.3 \%)$, maximum efficiency of PSII in the dark $\left(\mathrm{F}_{\mathrm{v}} / \mathrm{F}_{\mathrm{m}}\right)(\mathrm{V}=6.9 \%)$ and efficiency of PSII in the light
$\left(\mathrm{F}_{\mathrm{v}}, \mathrm{F}_{\mathrm{m}}\right)(\mathrm{V}=7.3 \%)$, were most stable, whereas mean growth rate $(\mathrm{V}=49.7 \%)$ and mean leaf assimilation surface area $(\mathrm{V}=46.82 \%)$ were most variable, which also indicates poor reproducibility of the latter traits (Table 3).

Under the experimental conditions, the chemical composition of tubers was associated with different degrees of the physiological indicators of potato growth. The dry matter content was determined by mean leaf assimilation surface area as well as chlorophyll $a$ and $b$ content in leaves. Reducing the assimilation surface area by $1 \mathrm{dm}^{-2}$ along with increasing the chlorophyll $a$ content by a unit and simultaneously decreasing the chlorophyll $b$ level in leaves by the standard deviation value around the arithmetic mean, assuming that the other factors are at their average levels, resulted in a change in dry matter content by values presented in Table 4 and Figure 1 . The determination coefficient for that equation (55.29\%) indicates that its components greatly determine dry matter accumulation in tubers; however, more than $44 \%$ of the trait variability is determined by factors that were not included in the regression model. 
Table 3. Statistical characteristics of independent variables $(x)$

\begin{tabular}{|c|c|c|c|c|c|c|c|c|c|}
\hline Description & $\begin{array}{c}\text { Arithme- } \\
\text { tical } \\
\text { mean }\end{array}$ & Median & $\begin{array}{l}\text { Standard } \\
\text { deviation }\end{array}$ & Kurtosis & $\begin{array}{l}\text { Skew- } \\
\text { ness }\end{array}$ & Range & $\begin{array}{l}\text { Mini- } \\
\text { mum }\end{array}$ & $\begin{array}{l}\text { Maxi- } \\
\text { mum }\end{array}$ & $\begin{array}{c}\text { Variation } \\
\text { coeffi- } \\
\text { cient } \\
\%\end{array}$ \\
\hline Mean leaf assimilation surface area $\mathrm{dm}^{-2}\left(x_{l}\right)$ & 0.18 & 0.01 & 0.08 & 0.32 & 0.85 & 0.45 & 0.03 & 0.48 & 46.82 \\
\hline Chlorophyll $a\left(x_{2}\right)$ & 0.65 & 0.59 & 0.17 & 0.10 & 0.91 & 0.80 & 0.41 & 1.21 & 26.46 \\
\hline Chlorophyll $b\left(x_{3}\right)$ & 0.22 & 0.22 & 0.03 & 0.81 & 0.52 & 0.17 & 0.15 & 0.32 & 13.98 \\
\hline Minimum fluorescence yield $\left(\mathrm{F}_{0}\right)\left(x_{4}\right)$ & 0.29 & 0.28 & 0.08 & -0.63 & 0.12 & 0.36 & 0.10 & 0.47 & 27.70 \\
\hline Maximum fluorescence yield $\left(\mathrm{F}_{\mathrm{m}}\right)\left(x_{5}\right)$ & 0.76 & 0.78 & 0.30 & -0.82 & 0.21 & 1.17 & 0.21 & 1.37 & 39.40 \\
\hline Maximum efficiency of PSII in the dark $\left(\mathrm{F}_{\mathrm{v}} / \mathrm{F}_{\mathrm{m}}\right)\left(x_{6}\right)$ & 0.69 & 0.37 & 0.10 & -0.81 & 1.29 & 0.53 & 0.13 & 0.66 & 6.90 \\
\hline Efficiency of PSII in the light $\left(\mathrm{F}_{\mathrm{v}} / \mathrm{F}_{\mathrm{m}}\right)\left(x_{7}\right)$ & 0.58 & 0.88 & 0.08 & 0.38 & 1.35 & 2.92 & 0.00 & 2.92 & 7.30 \\
\hline Maximum fluorescence efficiency $(\mathrm{Y})\left(x_{8}\right)$ & 0.36 & 0.28 & 0.11 & 1.51 & -0.25 & 0.48 & 0.13 & 0.59 & 31.39 \\
\hline Quantum yield of chlorophyll $\left(\Phi_{\mathrm{PSII}}\right)\left(x_{q}\right)$ & 0.48 & 0.46 & 0.03 & 2.32 & -1.18 & 0.10 & 0.39 & 0.85 & 6.30 \\
\hline $\begin{array}{l}\text { Coefficient of photochemical fluorescence } \\
\text { quenching }\left(\mathrm{q}_{\mathrm{p}}\right)\left(x_{10}\right)\end{array}$ & 0.58 & 0.55 & 0.03 & 0.60 & 0.41 & 0.54 & 0.31 & 0.48 & 5.20 \\
\hline $\begin{array}{l}\text { Coefficient of non-photochemical fluorescence } \\
\text { quenching }\left(\mathrm{q}_{\mathrm{n}}\right)\left(x_{11}\right)\end{array}$ & 0.09 & 0.09 & 0.01 & 0.21 & 0.15 & 0.05 & 0.13 & 0.18 & 11.1 \\
\hline Mean growth rate $\left(x_{12}\right)$ & 118.14 & 116.45 & 58.71 & 0.76 & 0.94 & 261.30 & 36.84 & 298.13 & 49.70 \\
\hline
\end{tabular}

Table 4. The value of partial coefficients of regression of chemical composition traits at a significance level of $p_{0.05}$ in relation to a change in the value of independent variables by a unit

\begin{tabular}{|c|c|c|c|c|c|c|c|c|c|}
\hline \multirow{2}{*}{ Traits } & \multirow{2}{*}{ Intercept } & \multicolumn{6}{|c|}{ Independent variables $(x)$} & \multirow{2}{*}{$\begin{array}{c}\text { Determination } \\
\text { coefficient } \\
\%\end{array}$} & \multirow{2}{*}{$\begin{array}{c}\text { Significance } \\
\qquad F\end{array}$} \\
\hline & & $x_{1}$ & $x_{2}$ & $x_{3}$ & $x_{4}$ & $x_{5}$ & $x_{12}$ & & \\
\hline Dry matter $\%\left(y_{1}\right)$ & 26.623 & -7.265 & 6.764 & -24.132 & & & & 55.29 & 0.030 \\
\hline Starch \% $\left(y_{2}\right)$ & 15.802 & -6.557 & 5.060 & & & -1.804 & & 53.73 & 0.018 \\
\hline Total sugars $\%\left(y_{3}\right)$ & 0.458 & & -0.058 & 0.132 & 0.047 & 0.022 & & 63.85 & 0.047 \\
\hline Reducing sugars $\%\left(y_{4}\right)$ & 0.150 & & -0.036 & 0.123 & & & & 53.63 & 0.046 \\
\hline Total protein $\%\left(y_{5}\right)$ & 1.895 & -0.666 & 0.738 & -1.707 & & & & 56.19 & 0.004 \\
\hline Specific protein $\%\left(y_{6}\right)$ & 1.166 & 0.442 & 0.179 & & & & & 35.06 & 0.001 \\
\hline Crude fibre $\%\left(y_{7}\right)$ & 0.519 & & & & & 0.050 & & 23.69 & 0.000 \\
\hline Ash \% $\left(y_{8}\right)$ & 1.267 & & 0.360 & -0.759 & & & & 38.67 & 0.004 \\
\hline Vitamin C $\mathrm{mg} \mathrm{kg}^{-1}\left(y_{9}\right)$ & 23.68 & & 3.769 & & & & & 43.63 & 0.009 \\
\hline Nitrates $\mathrm{mg} \mathrm{kg}^{-1}\left(y_{10}\right)$ & 64.639 & -473.475 & -8.810 & 1212.906 & 353.588 & 142.641 & -0.503 & 73.22 & 0.005 \\
\hline
\end{tabular}

Explanations of independent variables $(x)$ in Table 3

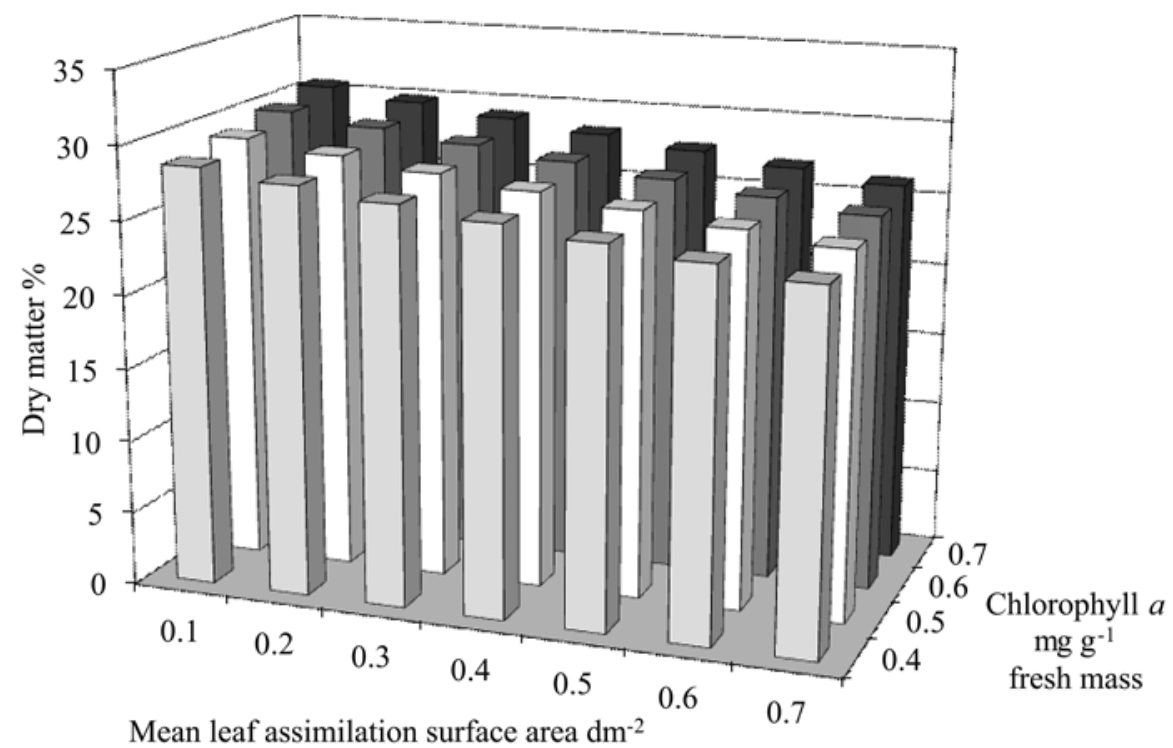

Figure 1. Partial dependence of regression of tuber dry matter on average leaf assimilation area and chlorophyll $a$ content during flowering 
Starch content was associated with mean leaf assimilation surface area, chlorophyll $a$ content in leaves and maximum efficiency of PSII in the dark. Reduction of assimilation of leaves and maximum photosynthetic capacity, within the standard deviation from the arithmetic mean, resulted in a reduction of the starch content in tubers
(Table 4, Fig. 2). The determination coefficient (D) for the equation $(\mathrm{D}=53.73 \%)$ indicates that its components greatly determined starch accumulation in tubers; more than $46 \%$ of the trait variability was determined by factors that were not included in the regression model.

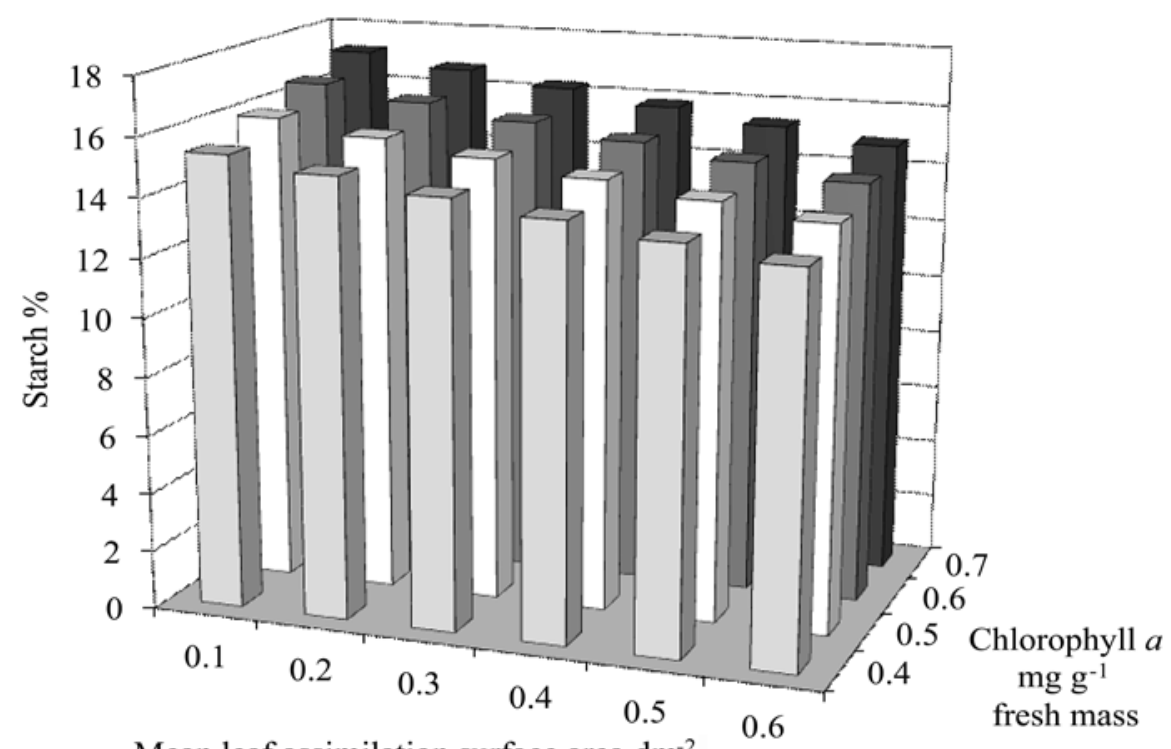

Figure 2. Partial dependence of regression of starch content on average leaf assimilation area and chlorophyll $a$ content during flowering

The level of total sugars, which determines the suitability of potato cultivars for foodstuff processing, appeared to be dependent on chlorophyll $a$ and $b$ contents in leaves as well as on minimum and maximum fluorescence yield. Decreasing the chlorophyll $a$ concentration by a unit and simultaneously increasing other physiological indicators - within the standard deviation range around the arithmetic mean - resulted in a change in total sugars content in tubers by values presented in Table 4. The determination coefficient amounted to $63.85 \%$, which indicates high reliability of the assumed regression model.
The concentration of reducing sugars in tubers, which affects the colour of potato fried products, was determined based on chlorophyll $a$ and $b$ contents. Lowering the chlorophyll $a$ content with increasing the chlorophyll $b$ content by a unit - within the standard deviation range around the arithmetic mean - contributed to a change in the quantity of these sugars by values presented in Table 4 and Figure 3. However, it should be underlined that the determination coefficient of the regression equation was not so high $(53.63 \%)$, indicating that this trait can be influenced by some other factors that were not included into the functional model.

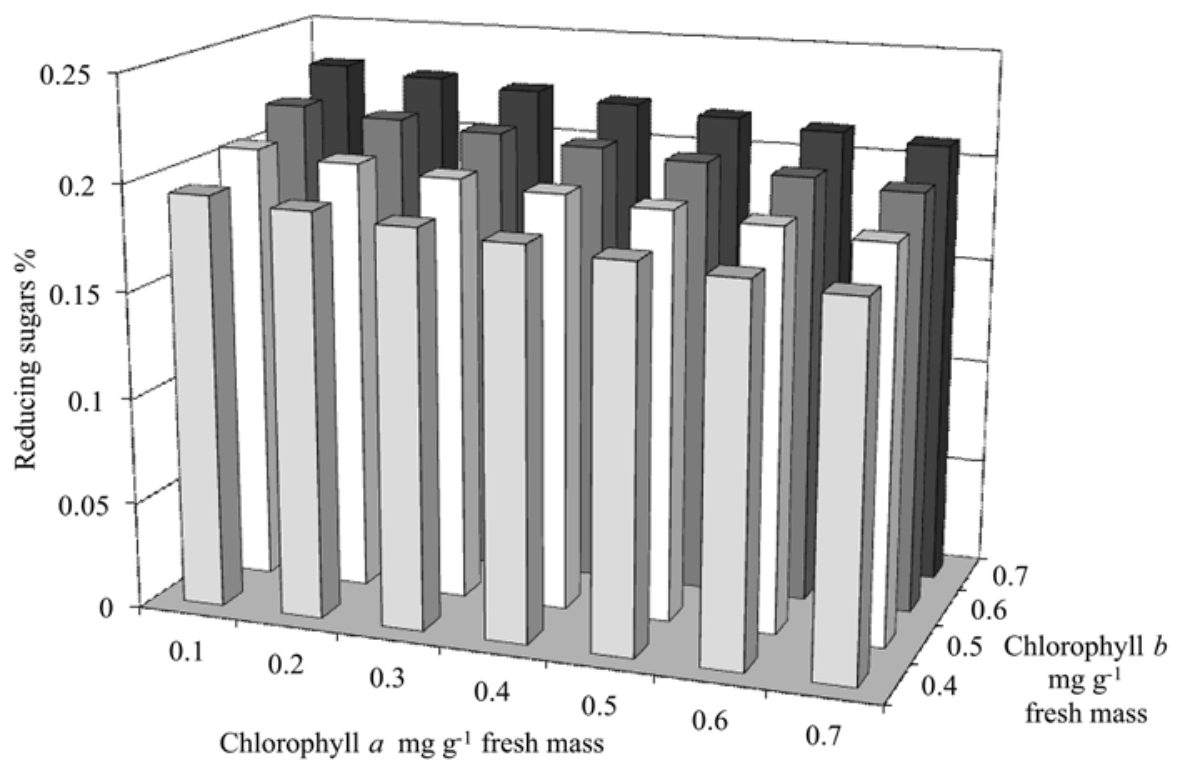

Figure 3. Partial dependence of regression of reducing sugar content on chlorophyll $a$ and $b$ content during flowering 
Total and specific protein content was significantly determined by mean leaf assimilation surface area and chlorophyll $a$ concentration in leaves. In the case of total protein, a reduction in leaf assimilation surface area and a decrease in chlorophyll $b$ content - within the standard deviation range around the arithmetic mean - had an effect of increasing protein levels; chlorophyll $a$ contents only reduced such trend by values presented in Table 4 . In the case of specific protein content, increasing leaf assimilation surface area and chlorophyll $a$ concentration - within the standard deviation range around the arithmetic mean - may determine the content of this component in potato tubers. Nevertheless, the determination coefficient for the latter regression equation was not high $(\mathrm{D}=35.06 \%)$, which indicates that other factors that were not assumed in the functional model influenced this feature.

Among the physiological factors analyzed, crude fibre accumulation in potato tubers was determined only by maximum fluorescence yield. Its increase by a unit - within the standard deviation range around the arithmetic mean - caused an increase in the content of this component in tubers by values presented in Table 4 . However, the determination coefficient for this regression equation was rather low and amounted to only $23.69 \%$, which indicates the possibility of other dependences that were not assumed in the functional model discussed. The ash content in tubers was influenced by chlorophyll $a$ and $b$ concentrations. An increase in chlorophyll $b$ content with a simultaneous increase in chlorophyll $a$ level by a unit - within the standard deviation range around the arithmetic mean - and assuming that other factors of the functional model remained at constant levels, contributed to lower accumulation of ashes in potato tubers (Table 4). The determination coefficient for this regression equation was not high, thus suggesting that the content of minerals in potato tubers could be determined by other parameters not included in the functional model adopted. Vitamin $\mathrm{C}$ accumulation - which determines the nutritional value of potato tubers - was only influenced by chlorophyll $a$ concentration in leaves. An increase in chlorophyll a concentration - within the standard deviation range around the arithmetic mean - resulted in an increase in vitamin $\mathrm{C}$ concentration by values presented in Table 4 and Figure 4.

The determination coefficient for this regression equation indicates a high dependence of this trait on chlorophyll $a$ content, although more than $50 \%$ of the feature variability is due to other factors that were not taken into account in the accepted functional model.

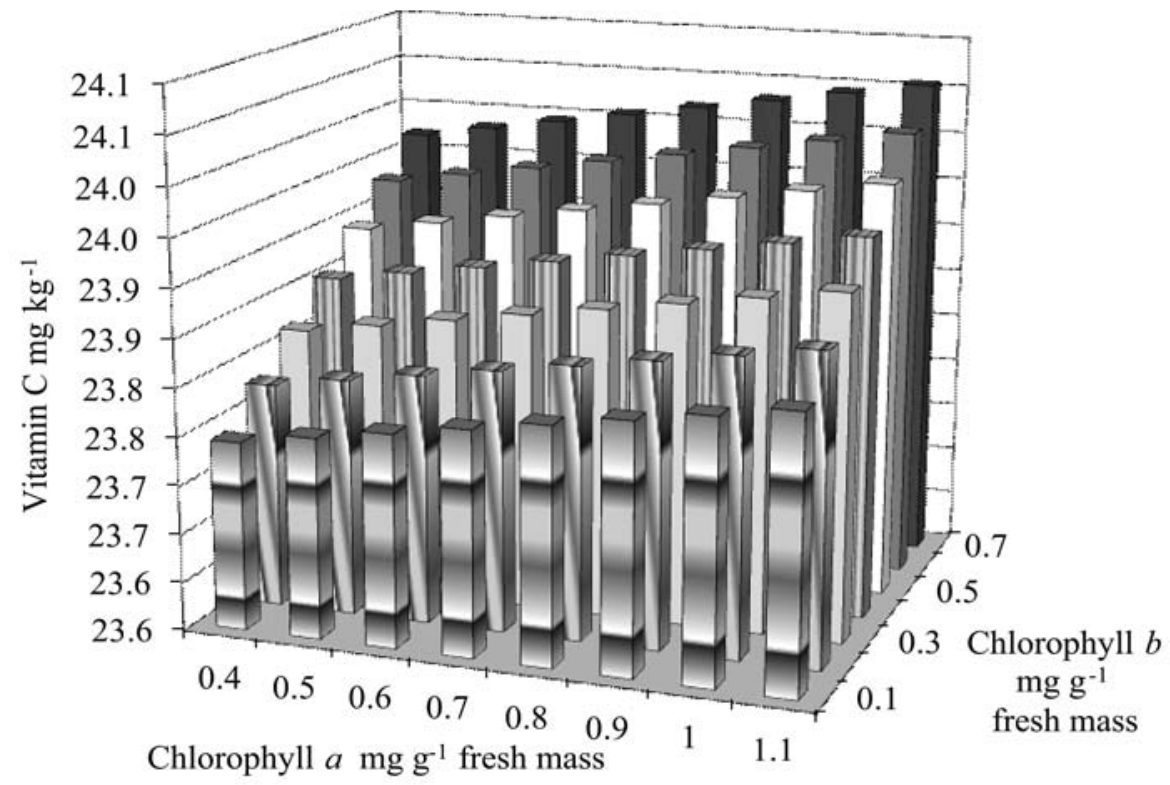

Figure 4. Partial dependence of regression of vitamin C content on chlorophyll $a$ and $b$ content during flowering

Nitrate levels in potato tubers were determined by a spectrum of physiological indicators such as: mean leaf assimilation surface area, chlorophyll $a$ and $b$ contents, minimum and maximum chlorophyll fluorescence yield, and mean growth rate. Reducing the mean leaf assimilation surface area, mean growth rate, and chlorophyll $a$ content in leaves along with increasing the chlorophyll $b$ concentration as well as minimum and maximum chlorophyll fluorescence yield by a unit within the standard deviation range around the arithmetic mean - determined the nitrates concentrations in tubers. Changes in the amounts of this form of nitrogen in tubers resulting from the above physiological factors are presented in Table 4 . The determination coefficient for the regression equation was high and amounted to $73.22 \%$, which makes it highly reliable.

\section{Discussion}

The dry matter, starch, sugars, total and specific proteins, crude fibre, ash, and vitamin C contents in potato tubers were comparable to the results achieved by Dua et al. (2013) as well as by Michałek and Sawicka (2005), while the nitrates concentration was within the range of permissible values for this component in potato tubers. Michałek and Sawicka (2005), Pereira and Villa Nova (2008), Pereira et al. (2008), Sadras et al. (2009) and 
Starck (2010) have reported that the existing differences in chemical composition of tubers are determined by cultivar phenotypic variability, which is a combined effect of genetic and environmental variability.

The present experiments revealed that the total sugar and vitamin $\mathrm{C}$ concentrations in the studied potato cultivars did not show any interaction with changing weather conditions. Other features of tuber chemical composition were found to be less stable and showed a significant interaction with the environment. In the research on potato cultivars, Pereira et al. (2008) indicated that starch content was the most stable and most reproducible trait of tuber chemical composition, for which genotypic variability played a prevalent role. Sadras et al. (2009) reported that the stability of chemical composition can be measured by similarity: the more similar are tuber properties of each particular cultivar, the more stable is a given feature. Mądry and Rajfura (2003) proved that in agricultural sense statistical stability of a trait occurs when the mean value of the trait in a particular cultivar or genotype changes proportionally to the average reaction of all cultivars or genotypes defined on the basis of the environmental mean value.

Coefficient of photochemical fluorescence quenching $\left(\mathrm{q}_{\mathrm{p}}\right)$ appeared to be the most stable indicator of chlorophyll fluorescence $(\mathrm{V}=5.2 \%)$, while mean leaf assimilation surface area the least stable indicator $(\mathrm{V}=$ $46.82 \%$ ). Mądry and Rajfura (2003) also found that this indicator was not very stable. Michałek and Sawicka (2005) found that higher stability of these features and different reactions of cultivars to weather conditions during the study were considered to be the main reason for their fluctuations. According to Mądry and Rajfura (2003), the variation coefficient is particularly recommended for ranking the importance of traits in multi-trait studies. Traits are considered to be stable when the variation coefficients do not exceed arbitrary values. The higher the variation coefficient, the less uniform set of observation units composes the sample. In such cases, positional variability measures such as range, interquartile range, relative quartile and deciles indicators are preferred.

The relative change in potential quantum efficiency of PSII $\left(\mathrm{F}_{\mathrm{v}} / \mathrm{F}_{\mathrm{m}}\right)$ appeared to be quite stable (V $=7.3 \%$ ). Starck (2010) reported that the functioning of PSII was the most sensitive indicator of the interactions of various factors affecting plants, which is useful in cultivation when selecting plants with a desirable genotype. Michałek and Sawicka (2005), when comparing the values of the parameter $\mathrm{F}_{\mathrm{v}} / \mathrm{F}_{\mathrm{m}}$ with the dry matter content in tubers; found that these values were greater for cultivars with higher yielding potential.

The values of the variation coefficient for photochemical $\left(\mathrm{q}_{\mathrm{p}}\right)$ and non-photochemical $\left(q_{n}\right)$ chlorophyll fluorescence quenching under the experimental conditions were low and therefore these traits were stable throughout the study period and were characterized by the most beneficial ratio of photons absorbed by PSII to photons used for open centres in photosynthesis reactions. According to Kocurek et al. (2009), Loboda (2010) and Starck (2014), it may indicate that under such circumstances no disturbance of the Calvin cycle is present in the studied cultivars, which can be associated with decreased utilization of a ATP (denosine triphosphate) during the dark phase of photosynthesis.

When considering the relationships between the contents of particular chemical components in potato tubers and physiological indicators, it was found that the chlorophyll level determined the concentrations of almost all chemical components studied, except for crude fibre. According to Starck (2010), the chlorophyll molecule is a very efficient photoreceptor, because it has double conjugated bonds. This type of molecules has strong absorption bands within the visible range absorbed by chlorophyll that makes it excited. The return of excited molecule to its general state is accompanied by radiation emission, i.e. fluorescence. However, the process is not $100 \%$ efficient; hence, fluorescence radiation is more long-waved as compared to light that invoked the fluorescence. Loboda (2010) reported that during different types of stress, e.g., at excessive radiation levels or low temperatures - the balance between supply of the socalled assimilation force ATP and NADPH (nicotinamide adenine dinucleotide phosphate-oxidase) produced by means of photochemical reactions and decreased demand for these products in enzymatic reactions of the dark phase of the Calvin-Benson cycle is disturbed. Such a situation forces the dissipation processes of energy absorbed by chlorophyll, which results, among others, in intensified fluorescence. According to Lamperski (2007), the excitation energy is transported within the areas of energetic antennas or between the so-called main pigments, i.e. chlorophyll $a$ and $b$ molecules or even it is transferred from auxiliary pigments ( $\beta$-carotenes) to the main ones and further between the main pigment molecules. Under optimal conditions, more than $90 \%$ of absorbed photons are transported through several photosystem from the antenna system to reaction centre. The excitation energy trapped in reaction centre makes it possible to perform the photochemical reaction of charge splitting, i.e. another phase of photosynthetic energy conversion.

Assimilation starch is an important carbohydrate that takes part in maintaining the homeostasis of donoracceptor balance within chloroplasts. Starck (2014) has indicated that starch accumulation results in reduced transport of photoassimilates out of this organelle. One possible reason for that can be decreased acceptor demands for photoassimilates during a stress, which most frequently results from their inhibited growth. During a drought, when potato tubers are poorly supplied with nutrients, starch accumulation is induced in chloroplasts (Gotsev et al., 2012). Starch is also accumulated in leaves due to various disturbances in carbohydrate metabolism or in the case of phosphorus deficits (Starck, 2014). Paul and Foyer (2001) as well as Cladiz (2009) reported that during disturbances in donor-acceptor balance of 
photoassimilates, carbohydrate accumulation occurs in leaves, along with decreased photosynthesis gene expression.

Minimum chlorophyll fluorescence yield had an effect only on the increased contents of total sugars and nitrates (Kalaji et al., 2012). According to Starck (2010), sugars, nitrates, ABA (abscisic acid), and cytokines affect the post-translation regulation of trehalose and T6P genes by stimulating the starch synthesis. Serine-threonine kinase (SnRK1) and kinases dependent on $\mathrm{Ca}^{2+}$ take part in the inactivation of TPS (syntaza Tre-6P) enzyme concomitantly with proteins. Therefore, the function of trehalose and its metabolites relates to carbohydrate metabolism. According to Paul and Foyer (2001), T6P gene influences both the synthesis and activity of ADP (adenosine diphosphate) by stimulating starch synthesis, which changes the ratio of supplied soluble carbohydrates to immobile starch. Under low light intensity conditions, sugar deficit contributes to growth inhibition, mainly in the roots of plants living in symbiosis with fungi.

The contents of specific protein, crude fibre, and ash did not show sufficient relationships with the physiological indicators analyzed. This may have resulted from the fact that cultivars with diverse physiological indicators have a similar chemical composition. Starck (2010) suggests that the increased quantities of total protein and nitrogen in potato tubers may result from more intensive RNA (ribonucleic acid) synthesis as well as from stimulating the synthesis of proteins necessary during the synthesis of many metabolic products and nucleic acids (DNA and RNA).

The mechanisms of photosynthesis and nutrient distribution processes under stress conditions are very complex, because they depend on the intensity and duration of those unfavourable circumstances. Starck (2010) has suggested that the intensity of photosynthesis has a major role, together with the distribution and activity of acceptors, because the coordination between photosynthesis and acceptor supply with photoassimilates depends not only on their physiological functions, but first of all on their variable activity under diverse habitat conditions. It seems that the mechanisms of growth correlations, which determine the maintenance of plant homeostasis, play the dominant role here. Competition for nutrients between acceptors also plays an important role under varied conditions of a cultivated field.

Applying polynomial regression analysis in statistical processing contributed to the explanation of the examined dependencies to a higher degree than it could be done using variance analysis of straight correlations. The determination coefficient for the majority of the equation sets presented here achieved the level of $50 \%$, which is postulated by numerous authors (Mądry, Rajfura, 2003); hence the adopted method can be considered to be fully reliable. The achieved results indicate the advisability of next studies on detailed selection of chlorophyll fluorescence parameters in respect to potato cultivars in order to predict tuber chemical composition during the growing period period (Kalaji et al., 2011; 2012).

\section{Conclusions}

1. Measuring the photosynthesis indicators such as maximum efficiency of photosystem (PS) II in the dark $\left(\mathrm{F}_{\mathrm{v}} / \mathrm{F}_{\mathrm{m}}\right)$, efficiency of PSII in the light $\left(\mathrm{F}_{\mathrm{v}} / \mathrm{F}_{\mathrm{m}}\right)$, quantum yield of chlorophyll $\left(\Phi_{\mathrm{PSII}}\right)$, as well as coefficient of photochemicalfluorescence quenching $\left(\mathrm{q}_{\mathrm{p}}\right)$ and coefficient of non-photochemical fluorescence quenching $\left(\mathrm{q}_{\mathrm{n}}\right)$ at different stages of potato plant development allowed more complete observation of plant growth, while an increase in the values of these parameters indirectly indicated the extension of the growing season of potato crops, which might directly affect potato yield and quality.

2. The stability of tuber chemical composition was higher than that of the chlorophyll fluorescence indicators, whereas the coordination between photosynthesis and acceptor supply with assimilates depended not only on the physiological indicators, but first of all on their activity under stress conditions.

3. Defined polynomial regression equations allowed us to predict changes in the contents of the analyzed components of potato tubers on the basis of selected photosynthesis indicators such as chlorophyll $a$ and $b$, minimum and maximum fluorescence yield, maximum efficiency of photosystem in the dark, and mean plant growth rate.

4. There is a possibility to apply selected chlorophyll fluorescence parameters to estimate tuber chemical composition for various potato cultivars and strains during the growing season.

5. The method of chlorophyll fluorescence can be used to assess the yield potential of potato.

Received 16122013

Accepted 20072014

\section{References}

AOAC 2012. Official methods of analysis (19 ${ }^{\text {th }}$ ed.) $<$ http:// www.aoac.org/iMIS15_Prod/AOAC/Publications/ Official_Methods_of_Analysis/AOAC_Member/ Pubs/OMA/AOAC_Official_Methods_of_Analysis. aspx?hkey $=5142 \mathrm{c} 478-\mathrm{ab} 50-4856-8939-\mathrm{a} 7 \mathrm{a} 491756 \mathrm{f} 48>$ [accessed 0206 2014]

Bahari A., Pirdashti H., Yaghubi M. 2013. The effects of amino acid fertilizers spraying on photosynthetic pigments and antioxidant enzymes of wheat (Triticum aestivum L.) under salinity stress. International Journal of Agronomy and Plant Production, 4 (4): 787-793

Baryłko-Pikielna N., Matuszewska I. 2014. Sensory food research. Basics - Methods - Applications ( $2^{\text {nd }}$ ed.). Polish Society of Food Technologists, 375 p. <http://www.pttz. org/zyw/wyd/ksiazki.html> (in Polish)

Brestic M., Zivcak M., Kalaji M. H., Carpentier R., Allakverdiev S. I. 2012. Photosystem II thermostability in situ: environmentally induced acclimation and genotypespecific reactions in Triticum aestivum L. Plant Physiology and Biochemistry, 57: 93-105

http://dx.doi.org/10.1016/j.plaphy.2012.05.012 
Caldiz D. O. 2009. Physiological age research during the second half of the twentieth century. Potato Research, 52: 295-304 http://dx.doi.org/10.1007/s11540-009-9143-4

Caldiz D. O., Fernandez L. V., Struik P. C. 2001. Physiological age index: a new, simple and reliable index to assess the physiological age of seed potato tubers based on haulm killing date and length of incubation period. Field Crop Research, 69 (1): 69-79 http://dx.doi.org/10.1016/S0378-4290(00)00134-9

Czyczylo-Mysza I., Tyrka M., Marcińska I., Skrzypek E., Karbarz M., Dziurka M., Hura T., Dziurka K., Quarrie S. A. 2013. Quantitative trait loci for leaf chlorophyll fluorescence parameters, chlorophyll and carotenoid contents in relation to biomass and yield in bread wheat and their chromosome deletion bin assignments. Molecular Breeding, 32 (1): 189-210 http://dx.doi.org/10.1007/s11032-013-9862-8

Dua V. K., Singh B. P., Govindakrishnan P. M., Kumar S., Lal S. S. 2013. Impact of climate change on potato productivity in Punjab - a simulation study research. Articles Current Science, 105 (6): 787-794

Gotsev V., Zaharieva I., Chernev P., Kouzmanova M., Kalaji M. H., Yordanov I., Krasteva V., Alexandrov V., Stefanov D., Allakverdiev S., Strasser R. J. 2012. Droughtinduced modifications of photosynthetic electron transport in intact leaves: analysis and use of neural networks as a tool for a rapid non-invasive estimation. Biochimica et Biophysica Acta: Bioenergetics, 1817: 1490-1498 http://dx.doi.org/10.1016/j.bbabio.2012.04.018

Kalaji M. H., Bosa K., Kościelniak J., Hossain Z. 2011. Chlorophyll $a$ fluorescence - a useful tool for the early detection of temperature stress in spring barley (Hordeum vulgare L.). OMICS: International Journal of Integrative Biology, 15 (12): 925-934 http://dx.doi.org/10.1089/omi.2011.0070

Kalaji M. H., Carpentier R. Allakhverdiev S. I., Bosa K. 2012. Fluorescence parameters as an early indicator of light stress in barley. Journal of Photochemistry and Photobiology B: Biology, 112: 1-6 http://dx.doi.org/10.1016/j.jphotobiol.2012.03.009

Kocurek M., Tokarz K., Pilarski J. 2009. Stem photosynthesis and its importance to the carbon budgets of plants. Botanical News, 53 (1-2): 7-20 (in Polish)

Kożuchowski K., Wibig J., Degirmendžić J. 2013. Meteorology and climatology. Warsaw, Poland, 324 p. (in Polish)

Lamperski J. 2007. Thermodynamic analysis of the photosynthetic process of concentration and bioconversion of solar energy into chemical energy of carbon. Report and Pre-20 series 16. Wroclaw, Poland (in Polish)

Loboda T. 2010. Chlorophyll fluorescence studies of the physiological condition of plants. Warsaw Agricultural University, Poland, 116 p. (in Polish)

Mądry W., Rajfura A. 2003. Statistical analysis measures the stability of the data in the classification of the genotypes $\times$ environment. Part I. The mixed model Scheffe-Caliński and combined regression model. Biometrical Colloquium, 33: 181-205 (in Polish)
Michałek W., Sawicka B. 2005. Chlorophyll content and fotosynthetic activity of medium-late potato cultivars in central-east Poland field conditions. Acta Agrophysica, 6 (1): 183-195 (in Polish)

Paul M. J., Foyer C. H. 2001. Sink regulation of photosynthesis. Journal of Experimental Botany, 52: 1383-1400

Pereira A. B., Villa Nova N. A. 2008. Potato maximum yield as affected by crop parameters and climatic factors in Brazil. Horticultural Science, 43 (5): 1611-1614

Pereira A. B., Villa Nova N. A., Ramos V. J., Pereira A. R. 2008. Potato potential yield based on climatic elements and cultivar characteristics. Bragantia Campinas, 67 (2): 327-334

PN-EN 12014-7:2001. Foodstuffs. Determination of nitrate and/ or nitrite. Part 7. Determination of nitrate in vegetables and vegetable products using a continuous flow, the reduction of cadmium. Warsaw, Poland (in Polish)

Sadras V., Calderini D., Connor D. 2009. Sustainable agriculture and crop physiology. Crop physiology. Sadras V. O., Calderini D. F. (eds). Applications for genetic improvement and agronomy. Burlington, USA, p. 1-20

Schreiber U., Bilger W., Hormann H., Neubauer C. 1997. Chlorophyll fluorescence as a diagnostic tool: the basics and some aspects of practical relevance. Raghavendra A. S. (ed.). Photosynthesis: a comprehensive treatise. Cambridge, UK, p. 320-336

Starck Z. 2010. Effect of stress conditions on coordination of photosynthetic production and resources allocation. Advances in Agricultural Sciences, 1: 9-26 (in Polish)

Starck Z. 2011. Plant in vivo - curiosity of the plant functions as compared with animal processes. Botanical News, 55 (1-2): 9-25 (in Polish)

Starck Z. 2014. Plant physiology: yesterday, today and what will bring tomorrow? Kosmos. Problems of Biological Sciences, 63 (4), 569-589 (in Polish)

Struik P. C. 2007. The canon of potato science: 40 . Physiological age of seed tubers. Potato Research, 50: 375-377 http://dx.doi.org/10.1007/s11540-008-9069-2 
ISSN 1392-3196 / e-ISSN 2335-8947

Zemdirbyste-Agriculture, vol. 102, No. 1 (2015), p. 41-50

DOI $10.13080 /$ z-a.2015.102.005

\title{
Bulvių gumbų cheminès sudėties ir fiziologinių rodiklių ryšys
}

\author{
B. Sawicka ${ }^{1}$, W. Michałek ${ }^{1}$, P. Pszczółkowski ${ }^{2}$ \\ ${ }^{1}$ Liublino gyvybès mokslų universitetas, Lenkija \\ ${ }^{2}$ Veislių tyrimo centro Veislių vertinimo bandymų stotis, Lenkija
}

\begin{abstract}
Santrauka
Straipsnyje pateikta keturiasdešimties veislių bulvių gumbų cheminès sudėties ir fiziologinių rodiklių dešimties metų tyrimų analizė. Tyrimai buvo atlikti Lenkijoje, Parczew bandymų stotyje, lengvame dirvožemyje po rugių keturiais pakartojimais pagal atsitiktinių imčių schemą. Iš keturiasdešimties tirtų bulvių veislių aštuonios buvo labai ankstyvos, septynios ankstyvos, devynios vidutiniškai vèlyvos ir septynios vèlyvos. Augalų fotosintetinis aktyvumas vertintas pagal bulvių lapų žalioje masėje spektrofotometriniu metodu nustatytą chlorofilo $a$ ir $b$ kiekį, taip pat lapuose fluorometru PAM-2000 išmatavus chlorofilo fluorescencijos indukciją. Skirtingais bulvių vystymosi tarpsniais išmatuoti fotosintezès rodikliai parodo, kad jų aukštesnis lygis yra netiesiogiai susijęs su augimo trukme ir gali turèti tiesioginès įtakos derliaus kokybei. Regresijos lygtis leido prognozuoti tirtų komponentų kiekių pokyčius bulvių gumbuose, remiantis chlorofilo $a$ ir $b$ kiekiu, minimalia ir maksimalia fluorescencijos išeiga, maksimaliu fotosistemos efektyvumu po užtamsinimo ir vidutiniu augalų augimo greičiu. Bulvių gumbų cheminė sudètis nustatyta taikant standartinius metodus. Tyrimo tikslas - nustatyti bulvių cheminę sudèti, priklausomai nuo chlorofilo fluorescencijos rodiklių verčių, kurios leidžia prognozuoti bulvių gumbų cheminę sudèti vegetacijos metu. Tyrimo rezultatai leidžia prognozuoti maisto medžiagų pokyčius bulvių gumbuose remiantis šiais rodikliais: chlorofilo $a$ ir $b$ kiekiu, minimalia ir maksimalia fluorescencijos išeiga, maksimaliu fotosistemos efektyvumu tamsoje ir augalų augimo greičiu.
\end{abstract}

Reikšminiai žodžiai: cheminè sudètis, chlorofilas, maksimalus fotosistemos efektyvumas, valgomoji bulvè, veislès. 